on safari. Finally, so many medical officers, specialists, and administrators in every country visited gave unstinting assistance and co-operation that mention of any names would be invidious. To one and all I offer my sincere thanks.

Figs. 1, 4, and 5 were produced in the Department of Medical Illustration in Makerere University College Medical School: Figs. 2 and 3 were produced by Dr. E. H. Williams, a companion in the road safari, and have been included by permission of the Editor of the British Journal of Cancer.
REFERENCES

Burkitt, D. (1958). Brit. J. Surg., 46, 218. (1962a). Postgrad. med. J., 38, 71 . (1962b). Ann. roy. Coll. Surg. Engl., 30, 211 (1962c). Nature (Lond.), 194, 232. (1962d). Brit. J. Cancer. In press. and Davies, J. N. P. (1961). Med. Press, 245, 367 and O'Conor, G. T. (1961). Cancer, 14, 258

Church, R. J. H. (1960). West Africa, 2nd ed., pp. 54, 482, 514. Longmans, London.

Marneffe, J. (1958). Ann. Soc. belge méd. trop., 38, 681 O'Conor, G. T. (1961). Cancer, 14, 270. and Davies, J. N. P. (1960). Pediatrics, 56, 526.

\title{
RHEUMATIC FEVER AND THE BLOOD GROUPS*
}

BY

\section{J. A. BUCKWALTER, M.D. G. S. NAIFEH, M.D.}

\section{J. E. AUER}

Department of Surgery, College of Medicine, State University of lowa

There is general agreement that group A haemolytic streptococcal infections of the upper respiratory tract are causally related to rheumatic fever. It is not understood why a few individuals develop rheumatic fever following such throat infections while most do not. This important question, the subject of many investigations most of which have been from an immunological point of view, remains without a satisfactory answer.

There is evidence to suggest that the presence of the mucopolysaccharide blood-group substances in saliva is related to susceptibility to rheumatic fever (Glynn and Holborow, 1961). These authors have suggested (Glynn and Holborow, 1952) that streptococci possibly convert blood-group substances to antigens which might then participate in the pathogenesis of rheumatic fever.

The evidence suggesting an association between the $\mathrm{ABO}$ blood groups and rheumatic fever is not as strong as that for the association to $\mathrm{ABO}(\mathrm{H})$ secretion. If there is a blood-group association, it could (a) simply reflect the "effect" of a blood-group substance being secreted in the saliva as suggested above, or $(b)$ it might reflect a more general "effect" of gene action on enzymatic activity and cellular metabolism.

In this report the present status of our studies dealing with the possible association of the blood groups to rheumatic fever is described. The previously reported data suggesting an ABO-blood-group association for rheumatic fever are included (Buckwalter et al., 1958). The findings of the $\mathrm{ABO}$, rhesus, and $\mathrm{MN}$ blood groups, of the $\mathrm{ABO}(\mathrm{H})$ saliva secretion, and of the sibship studies are reported. The results obtained when our data are combined with those of other investigators and statistically evaluated are included in this communication. Finally, a working hypothesis is formulated on the basis of data recorded and discussed in this report.

\section{Materials and Methods}

All our data have been obtained from patients seen at the University of Iowa Hospitals during the past 15 years. The diagnoses have been established on clinical grounds or on the basis of operative findings. Blood and saliva samples were obtained from the patients and blood samples from their siblings. The standard-titre group-specific antisera used to type the

*These researches were made possible by grants RG-4777 and A-3778 from the National Institutes of Health. blood were: A, B, absorbed anti-A, $\mathrm{Rh}_{\mathrm{o}}, \mathrm{rh}^{\prime}, \mathrm{rh}^{\prime \prime}, \mathrm{hr}^{\prime}$, $\mathrm{M}, \mathrm{N}$, and anti-human. The techniques employed were those recommended by the supplier of the antisera. It is relevant to the results and important to point out that all the blood typings were performed by the same technician. An isohaemagglutination test, using anti-A and $B$ sera and anti-O $(\mathbf{H})$ in the form of a mixture made from ground Ulex europaeus seeds and $0.9 \%$ $\mathrm{NaCl}$, was employed to determine the presence of bloodgroup substances in the saliva specimens.

Several different kinds of controls were used in ascertaining the statistical significance of the patient data. The 49,979 blood donors described in detail in a previous communication (Buckwalter and Knowler, 1958) were used to assess the total ABO findings (controls $\mathrm{I}$ ). To evaluate the $\mathrm{ABO}$ subgroup $\left(\mathrm{A}_{1}, \mathrm{~A}_{2}\right.$, $A_{1} B, A_{2} B$ ), rhesus and $M N$ blood groups, and salivasecretion data a random sample of physicians, students, technicians, spouses of the patients, and patients with diagnoses other than those being studied were used as controls (II). Unaffected siblings of the patients provided a third set of controls (III). In another communication the reasons for using unaffected siblings as controls for blood-group disease studies have been discussed (Buckwalter et al., 1960).

A modification of the method described by Woolf (1955) has been used to arrive at the statistical significance of the data. This method evaluates the significance of the differences in the incidence of the disease in the patients of the different blood groups. The incidences are determined from the blood-type frequencies observed in the patients and the controls. This is a more direct and natural way to think of the blood-group association than in terms of an increase or decrease in the patients' blood-group frequencies compared with control blood-group frequencies. This method has the added advantage of making it possible to combine and analyse data collected by independent investigators. The use of two programmes which have been written for the IBM 7070 digital computer by Dr. Edwards greatly facilitates the statistical analysis of the data. The results obtained when the data are examined by the conventional $\lambda^{2}$ method are given in another communication (Buckwalter and Tweed, 1962). A method devised by C. A. Smith, as described by Clarke et al. (1956), was used in determining the statistical significance of the sibling data. 


\section{Results}

Table I records the numbers and percentages of patients and controls (I) of each $\mathrm{ABO}$ blood group. The rheumatic-fever patients were subdivided by sex and by whether or not surgery had been performed for the treatment of mitral valvular heart disease. The 180 patients indicated as having other collagen vascular diseases were composed of patients with rheumatoid arthritis, periarteritis nodosa, dermatomyositis, and lupus erythematosus. In Table II the incidence of the disease

TABLE I.-Number and Percentage of Rheumatic-fever (Subdivided by Sex and Treatment) and Other Collagen-vasculardisease Patients and Controls (I) of Each ABO Blood Group

\begin{tabular}{|c|c|c|c|c|c|c|c|}
\hline & $\begin{array}{c}\text { Controls } \\
\text { (I) }\end{array}$ & $\begin{array}{l}\text { Rheu- } \\
\text { matic } \\
\text { Fever }\end{array}$ & Male & Female & Surgery & $\begin{array}{c}\text { No } \\
\text { Surgery }\end{array}$ & $\begin{array}{l}\text { Other } \\
\text { Collagen } \\
\text { Vascular } \\
\text { Diseases }\end{array}$ \\
\hline $0\left\{\begin{array}{l}\text { No. } \\
\%\end{array}\right.$ & $\begin{array}{l}22,392 \\
44 \cdot 8\end{array}$ & $\begin{array}{l}301 \\
40 \cdot 0\end{array}$ & $\begin{array}{l}107 \\
41.5\end{array}$ & $\begin{array}{l}194 \\
39 \cdot 3\end{array}$ & $\begin{array}{l}93 \\
42 \cdot 5\end{array}$ & $\begin{array}{l}208 \\
39 \cdot 0\end{array}$ & $\begin{array}{l}79 \\
43 \cdot 9\end{array}$ \\
\hline A $\left\{\begin{array}{l}\text { No. } \\
\%\end{array}\right.$ & $\begin{array}{l}21,144 \\
42 \cdot 3\end{array}$ & $\begin{array}{l}344 \\
45 \cdot 7\end{array}$ & $\begin{array}{l}122 \\
47 \cdot 3\end{array}$ & $\begin{array}{l}222 \\
44.9\end{array}$ & $\begin{array}{l}88 \\
40 \cdot 2\end{array}$ & $\begin{array}{l}256 \\
48 \cdot 0\end{array}$ & $\begin{array}{l}70 \\
38.9\end{array}$ \\
\hline B $\left\{\begin{array}{l}\text { No. } \\
\%\end{array}\right.$ & $\begin{array}{l}4,695 \\
9 \cdot 4\end{array}$ & $\begin{array}{l}73 \\
9 \cdot 8\end{array}$ & $\begin{array}{l}24 \\
9 \cdot 3\end{array}$ & $\begin{array}{l}49 \\
9 \cdot 9\end{array}$ & $\begin{array}{l}26 \\
11.9\end{array}$ & $\begin{array}{l}47 \\
8 \cdot 8\end{array}$ & $\begin{array}{l}23 \\
12 \cdot 8\end{array}$ \\
\hline AB $\left\{\begin{array}{l}\text { No. } \\
\%\end{array}\right.$ & $\begin{array}{l}1,748 \\
3 \cdot 5\end{array}$ & $\begin{array}{l}34 \\
4 \cdot 5\end{array}$ & $\begin{array}{l}5 \\
1.9\end{array}$ & $\begin{array}{l}29 \\
5.9\end{array}$ & $\begin{array}{l}12 \\
5 \cdot 5\end{array}$ & 22 & $\begin{array}{l}8 \\
4 \cdot 4\end{array}$ \\
\hline Total & 49,979 & 752 & 258 & 494 & 219 & 533 & 180 \\
\hline
\end{tabular}

TABLE II.-Relative Incidence (RI) Based Upon Blood-type Frequencies of Patients and Controls (I) and the $\chi^{2}$ Values Obtained Using the Woolf Method

\begin{tabular}{|c|c|c|c|c|c|c|}
\hline $\begin{array}{c}\text { Groups } \\
\text { Compared }\end{array}$ & $\begin{array}{l}\text { Rheu- } \\
\text { matic } \\
\text { Fever }\end{array}$ & Male & Female & Surgery & $\begin{array}{c}\text { No } \\
\text { Surgery }\end{array}$ & $\begin{array}{l}\text { Other } \\
\text { Collagen } \\
\text { Vascular }\end{array}$ \\
\hline $\left.\begin{array}{l}\text { A to O } \\
\text { B to } 0 \\
\text { A B to O } \\
\begin{array}{c}\text { Non-O to } \\
\text { O }\end{array}\end{array}\right\}\left\{\begin{array}{l}\mathrm{R} \\
\chi_{2} \\
\mathrm{R} \\
\chi_{2} \\
\mathrm{R} \\
\chi_{2} \\
\mathrm{R} \\
\chi_{2}\end{array}\right.$ & $\begin{array}{l}1.15 \\
5.78 * \\
1.04 \\
1.22 \\
1.31 \\
4.08 \\
1.22 \\
6.83^{* *}\end{array}$ & $\begin{array}{l}1.22 \\
2.01 \\
0.98 \\
0.09 \\
0.55 \\
1.26 \\
1 \cdot 16 \\
1 \cdot 15\end{array}$ & $\begin{array}{l}1 \cdot 11 \\
3.77^{*} \\
1.06 \\
1.34 \\
1.72 \\
10 \cdot 47^{* *} \\
1.26 \\
6 \cdot 03^{*}\end{array}$ & $\begin{array}{l}0.92 \\
0.10 \\
1.30 \\
1.67 \\
1.60 \\
2.66 \\
1.10 \\
0.48\end{array}$ & $\begin{array}{l}1.26 \\
7.98 * * \\
0.93 \\
0.21 \\
1.19 \\
1.81 \\
1.97 \\
7.09 * *\end{array}$ & $\begin{array}{l}0.87 \\
0.15 \\
1.41 \\
1.92 \\
1.28 \\
0.50 \\
1.04 \\
0.06\end{array}$ \\
\hline
\end{tabular}

in patients of groups $\mathrm{A}, \mathrm{B}, \mathrm{AB}$, and the combined non-O relative to the incidence in group $O$ persons determined from the blood-type frequencies of the patients and controls (I) is indicated (RI). For example, taking the data from Table I and using Woolf's method,

$$
\mathrm{RI} \text { of } \mathrm{A} \text { to } \mathrm{O}=
$$

Rheumatic fever patients group $\mathrm{A} \times$ controls group $\mathrm{O}$ Rheumatic fever patients group $\mathrm{O} \times$ controls group $\mathrm{A}=$

$$
\frac{344 \times 22,392}{301 \times 21,144}=1.2
$$

The $\chi^{2}$ values are recorded; those that are statistically significant are indicated. The data indicate a statistically significant decrease in the incidence of rheumatic fever in persons of blood type $O$. This is shown best by the comparison of patients with non- $\mathrm{O}$ and $\mathrm{O}$ blood groups. The differences between female and non-surgical non-O and $O$ patients are also statistically significant. The highest $\chi^{2}$ value of all is found for the comparison of the incidence of rheumatic fever in females of group $A B$ and group $O$. None of the findings in the patients with the other collagen vascular diseases were statistically significant.

In Table III are recorded the $\mathrm{ABO}$ subgroup $\left(\mathrm{O}, \mathrm{A}_{1}\right.$, $A_{2}, B, A_{1} B, A_{2} B$ ) findings for the rheumatic-fever patients and the controls (II). The saliva-secretion findings are recorded in Table IV. The apparent discrepancies in the numbers of the patients and of the controls in the various tables indicate that not all the patients or all of the controls had their secretor status determined or were typed for the ABO subgroup, rhesus, and $\mathrm{MN}$ groups. There were 752 patients with rheumatic fever who had the four ABO blood types determined, 540 in whom the ABO subtype and the MN type were determined, and 538 who had their rhesus blood type determined; the secretor status was determined of 376 of the rheumatic-fever patients.

TABLE III.-Number and Percentage of Rheumatic-fever Patients and Controls (II) of Groups $O, A_{1}, A_{2}, B, A_{1} B$, and $A_{2} B$

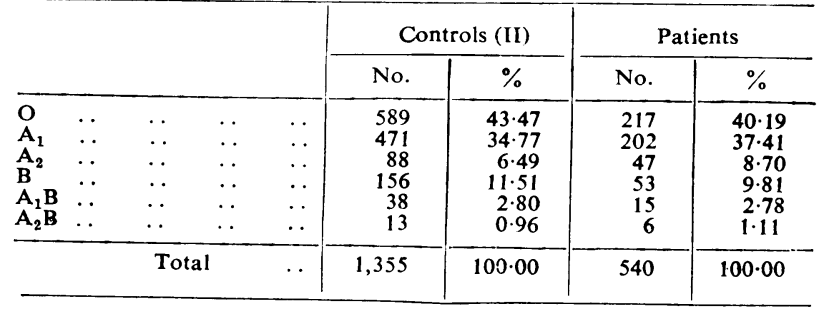

TABLE IV.-Number and Percentage of Rheumatic-fever Patients and Controls (II) Who are $A B O(H)$ Blood-group-substance

\begin{tabular}{|c|c|c|c|c|c|c|c|c|c|c|}
\hline & & & \multicolumn{4}{|c|}{ Controls II } & \multicolumn{4}{|c|}{ Rheumatic Fever } \\
\hline & & & \multicolumn{2}{|c|}{ Secretors } & \multicolumn{2}{|c|}{$\begin{array}{l}\text { Non- } \\
\text { secretors }\end{array}$} & \multicolumn{2}{|c|}{ Secretors } & \multicolumn{2}{|c|}{$\begin{array}{c}\text { Non- } \\
\text { seeretors }\end{array}$} \\
\hline & & & No. & $\%$ & No. & $\%$ & No. & $\%$ & No. & $\%$ \\
\hline $\begin{array}{l}\mathbf{O} \\
\mathbf{A}_{1} \\
A_{2} \\
\mathbf{B}_{2} \\
\mathbf{A}_{1} \mathbf{B} \\
\mathbf{A}_{2} \mathbf{B} \\
\end{array}$ & $\begin{array}{l}. \\
\therefore \\
\because \\
\therefore \\
\therefore \\
\end{array}$ & $\because$ & $\begin{array}{r}447 \\
322 \\
65 \\
107 \\
22 \\
8\end{array}$ & $\begin{array}{l}79 \cdot 40 \\
75.94 \\
73.86 \\
74.31 \\
71.97 \\
72.73 \\
\end{array}$ & $\begin{array}{r}16 \\
102 \\
23 \\
37 \\
9 \\
3 \\
\end{array}$ & $\begin{array}{l}20 \cdot 60 \\
24 \cdot 06 \\
26.14 \\
25.69 \\
29.03 \\
27.27 \\
\end{array}$ & $\begin{array}{r}109 \\
111 \\
20 \\
27 \\
9 \\
3 \\
\end{array}$ & $\begin{array}{l}75.17 \\
76.55 \\
58.82 \\
71.05 \\
81.82 \\
100.00 \\
\end{array}$ & \begin{tabular}{r|}
36 \\
34 \\
14 \\
11 \\
2 \\
0 \\
\end{tabular} & $\begin{array}{c}24.83 \\
23.45 \\
41.18 \\
28.95 \\
18.18 \\
- \\
\end{array}$ \\
\hline \multicolumn{3}{|c|}{ Total } & 971 & $100 \cdot 00$ & 290 & $100 \cdot 00$ & 279 & $100 \cdot 00$ & 97 & 100.00 \\
\hline
\end{tabular}
Secretors and Non-secretors by Blood Group

Table $\mathrm{V}$ records the incidence of rheumatic fever in persons of $A_{1}, A_{2}, B, A_{1} B, A_{2} B$, and the combined non-O blood groups relative to the incidence of the disease in group $O$ persons (RI) ; the relative incidence (RI) of the disease in non-secretors to secretors is also shown. The $\chi^{2}$ value for each of the comparisons is given. The data reveal a decreased incidence of rheumatic fever in persons of blood group $O$. When the incidence in group $O$ is compared with that in the other groups the largest differences are found for the $\mathrm{O}: \mathrm{A}$ and $\mathrm{O}:$ non- $\mathrm{O}$ comparisons. However, these differences are not statistically significant. None of the secretion:nonsecretion differences for specific blood groups using the patient and the control data recorded in Table IV are statistically significant (results of analysis are not shown). However, when the secretion findings for the combined $\mathrm{ABO}$ blood groups of the patients and the controls are compared (Table $\mathrm{V}$ ) the incidence of the disease is found to be significantly increased in non-secretors - that is, the frequency of the non-secretion is significantly higher in the patients than in the controls.

The unaffected siblings which were used as controls (III) were obtained from the families of the 157 rheumatic fever patients that segregated for group $\mathrm{O}-$ that is, there were group $\mathrm{O}$ and non- $\mathrm{O}$ group siblings

TABLE V.-Relative Incidence (RI) Based Upon the Blood Type and $A B O(H)$ Secretion Frequencies of Rheumatic-fever Patients and Controls (II) and the $x^{2}$ Values Obtained Using the Woolf Method

\begin{tabular}{c|c|c|c|c|c|c|c}
\hline & $\begin{array}{c}\mathrm{A}_{1} \text { to } \\
\mathrm{O}\end{array}$ & $\begin{array}{c}\mathrm{A}_{2} \text { to } \\
\mathrm{O}\end{array}$ & $\begin{array}{c}\mathrm{B} \text { to } \\
\mathrm{O}\end{array}$ & $\begin{array}{c}\mathrm{A}_{1} \mathrm{~B} \text { to } \\
\mathrm{O}\end{array}$ & $\begin{array}{c}\mathrm{A}_{2} \mathrm{~B} \text { to } \\
\mathrm{O}\end{array}$ & $\begin{array}{c}\text { Non-O } \\
\text { to O }\end{array}$ & $\begin{array}{c}\mathrm{Se}+\text { to } \\
\text { to } \mathrm{Se}-\end{array}$ \\
\hline $\begin{array}{c}\mathrm{R} 1 \\
\chi^{2}\end{array}$ & $\begin{array}{c}1.16 \\
1.73\end{array}$ & $\begin{array}{c}1.45 \\
3.54\end{array}$ & $\begin{array}{c}0.92 \\
0.21\end{array}$ & $\begin{array}{c}1.07 \\
0.05\end{array}$ & $\begin{array}{c}1.25 \\
0.20\end{array}$ & $\begin{array}{c}1.14 \\
1.70\end{array}$ & $\begin{array}{c}1.15 \\
1.26\end{array}$ \\
\hline
\end{tabular}


in these 157 families. In Table VI are recorded the results obtained when the frequency of group $O$ of the patients or propositi (observed) is compared with the frequency of group $O$ in their unaffected siblings (expected) by Smith's method (Clarke et al., 1956). The ratio of numbers found to numbers expected, $1-16$, is similar to the population relative incidence, and entirely consistent with our interpretation that the association is not due to inappropriate controls.

In Table VII are recorded the rhesus blood-group findings in the rheumatic-fever patients and the controls. The results obtained when these data are examined for statistical significance by the method of Woolf are recorded in Table VIII. The common presumptive rhesus genotypes are referred to as the rhesus blood groups in this communication. The incidence of rheumatic fever in persons of $R_{1} R_{1}, R_{1} r, R_{1} R_{2}, R_{2} r, R_{0} r$, $\left(r^{\prime} r^{\prime \prime}\right) r$, and the combined non-rr genotypes has been compared with the incidence in persons of $\mathrm{rr}$ genotype. The $R_{2} r: r r$ and the $\left(r^{\prime} r^{\prime \prime}\right) r: r r$ differences are statistically significant, as indicated in Table VIII.

In Table IX are recorded the MN blood-group findings in the rheumatic-fever patients and controls. The results obtained when these data are examined for

Table VI.-Analysis of the Chance of the Propositus Being Group $O$ in the Sibships Segregating for Blood Group $O$

\begin{tabular}{c|c|c|c|c}
\hline & $\begin{array}{c}\text { No. of } \\
\text { Sibships }\end{array}$ & $\begin{array}{c}\text { Group O } \\
\text { Observed }\end{array}$ & $\begin{array}{c}\text { Group O } \\
\text { Expected }\end{array}$ & Variance \\
\hline Rheumatic fever .. & 157 & 63 & $73 \cdot 3$ & 33.9 \\
\hline
\end{tabular}

From which we obtain :

$73 \cdot 2993-63$

$\sqrt{33 \cdot 8798}$

TARLE VII --Number and Percentage of Rheumatic-fever Patients and the Controls (II) of the Common Presumptive Rhesus Genotypes

\begin{tabular}{|c|c|c|c|c|c|c|}
\hline & & & \multicolumn{2}{|c|}{ Controls } & \multicolumn{2}{|c|}{ Patients } \\
\hline & & & No. & $\%$ & No. & $\%$ \\
\hline $\begin{array}{l}\mathrm{rr} \\
R_{1} R_{1} \\
R_{1} r \\
R_{1} R_{2} \\
R_{2} r^{2} \\
R_{0} r \\
\left(r^{\prime} r^{\prime \prime}\right) r\end{array}$ & $\begin{array}{l}\ldots \\
\because \\
\cdots \\
\cdots \\
\cdots\end{array}$ & $\begin{array}{l}\ldots \\
\cdots \\
\cdots \\
\cdots \\
\cdots\end{array}$ & $\begin{array}{r}338 \\
382 \\
723 \\
303 \\
319 \\
91 \\
25\end{array}$ & $\begin{array}{r}15 \cdot 50 \\
17 \cdot 51 \\
33 \cdot 15 \\
13 \cdot 89 \\
14.63 \\
4.17 \\
1.15\end{array}$ & $\begin{array}{r}72 \\
81 \\
173 \\
78 \\
97 \\
22 \\
15\end{array}$ & $\begin{array}{r}13.38 \\
15.06 \\
32.16 \\
14.50 \\
18.03 \\
4.09 \\
2.78\end{array}$ \\
\hline \multicolumn{2}{|c|}{ Total } & $\ldots$ & 2,181 & $100 \cdot 00$ & 538 & $100 \cdot 00$ \\
\hline
\end{tabular}

TABLE VIII.-Relative Incidence $(R I)$ and $\chi^{2}$ Values Obtained from Rheumatic-fever Patient and Control (In) Rhesus Blood-group Data

\begin{tabular}{|c|c|c|c|}
\hline Group & Compared & RI & $\chi^{3}$ \\
\hline $\begin{array}{l}R_{1} R_{1} \text { to } r r \\
R_{1} r \text { to } r r \\
R_{1} R_{2} \text { to } r r \\
R_{2} r \text { to } r r \\
R_{0} r \text { to } r r \ldots \\
\left.\text { (r } r^{\prime} r^{\prime \prime}\right) r \text { to } r r \\
\text { Non-rr to } r r\end{array}$ & 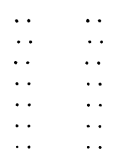 & $\begin{array}{l}1.00 \\
1.12 \\
1.21 \\
1.43 \\
1.14 \\
2.82 \\
1.19\end{array}$ & $\begin{array}{l}0.01 \\
0 \cdot 56 \\
1 \cdot 09 \\
4 \cdot 18 * \\
0 \cdot 22 \\
8 \cdot 68 * * \\
1 \cdot 50\end{array}$ \\
\hline
\end{tabular}

TABle IX.-Number and Percentage of Rheumatic-fever Patients and Controls (II) of Each MN Blood Group

\begin{tabular}{c|c|c|c|c}
\hline & \multicolumn{2}{|c|}{ Controls } & \multicolumn{2}{c}{ Patients } \\
\cline { 2 - 4 } & No. & $\%$ & No. & $\%$ \\
\hline MM & 587 & 26.85 & 128 & $23 \cdot 70$ \\
MN & 1,208 & 55.26 & 284 & 52.59 \\
NN & 391 & 17.89 & 128 & 23.70 \\
\hline Total & 2,186 & 100.00 & 540 & 100.00 \\
\hline
\end{tabular}

statistical significance by the method of Woolf are recorded in Table $X$. The increased incidence of rheumatic fever in persons of blood group $\mathrm{N}$ is statistically significant.

TABLE X.-Relative Incidences $(R I)$ and $\chi^{2}$ Values Obtained from Rheumatic-fever Patient and Control (II) MN Blood-group Data

\begin{tabular}{|c|c|c|}
\hline Groups Compared & RI & $\chi^{2}$ \\
\hline $\begin{array}{l}\text { MN to MM } \\
\text { NN to MM } \\
\text { Non-MM to MM }\end{array}$ & $\begin{array}{l}1 \cdot 08 \\
1.50 \\
1 \cdot 18\end{array}$ & $\begin{array}{l}0 \cdot 41 \\
8 \cdot 30^{*} \\
2 \cdot 22\end{array}$ \\
\hline
\end{tabular}

\section{Discussion}

Evidence for an association between the $\mathrm{ABO}$ blood groups and rheumatic fever or of an $\mathrm{ABO}$ blood-group " effect" characterized by an increased susceptibility to the disease of persons of blood groups $A_{1}, A_{2}, A_{1} B$, and $A_{2} B$ and a relatively marked resistance to the disease in persons of blood group $\mathrm{O}$ has also been found by other investigators. Our data are combined with those reported by other investigators in Table XI. Note that 771 Iowa rheumatic-fever patients are indicated. The apparent discrepancy from Table I, 752 patients, represents the additional patients who were seen during the interval required for analysis of the data. The

TABLE XI.-Pooled Rheumatic Fever ABO Blood-group Data Analysed by Woolf's Method

\begin{tabular}{|c|c|c|c|c|c|c|c|}
\hline & & \multicolumn{2}{|c|}{ Controls } & \multicolumn{2}{|c|}{ Patients } & \multirow[b]{2}{*}{ RI } & \multirow[b]{2}{*}{$x^{2}$} \\
\hline & & $\begin{array}{c}\text { Non- } \\
\text { group O }\end{array}$ & $\begin{array}{c}\text { Group } \\
\text { O }\end{array}$ & $\begin{array}{c}\text { Non- } \\
\text { group O }\end{array}$ & $\begin{array}{c}\text { Group } \\
\text { O }\end{array}$ & & \\
\hline 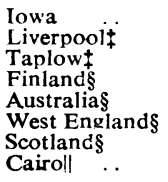 & $\begin{array}{l}\ldots \\
\ldots \\
\ldots \\
\ldots \\
\ldots \\
\ldots\end{array}$ & $\begin{array}{r}27,587 \\
8,215 \\
8,271 \\
25,123 \\
623 \\
2,247 \\
2,720 \\
6,402\end{array}$ & $\begin{array}{r}22,392 \\
7,842 \\
6,775 \\
12,319 \\
500 \\
2,141 \\
3,177 \\
3,598\end{array}$ & $\begin{array}{r}463 \\
158 \\
354 \\
183 \\
149 \\
106 \\
257 \\
88\end{array}$ & $\begin{array}{r}308 \\
105 \\
255 \\
88 \\
111 \\
94 \\
281 \\
32\end{array}$ & $\begin{array}{l}1.22 \\
1.44 \\
1.14 \\
1.02 \\
1.08 \\
1.08 \\
1.07 \\
1.55\end{array}$ & $\begin{array}{l}7 \cdot 22 * * \\
8 \cdot 15 * * \\
2 \cdot 35 \\
0 \cdot 02 \\
0 \cdot 29 \\
0 \cdot 25 \\
0 \cdot 54 \\
4 \cdot 40\end{array}$ \\
\hline
\end{tabular}

Association d.f. $1 ; \chi^{2} 15 \cdot 56 * * *$. Heterogeneity d.f. $7 ; \chi^{2} 7.65$.
$* \mathrm{P}<0.05$. $* * \mathrm{P}<0.01$. $* * * \mathrm{P}<0.001$.

$\ddagger$ Clarke et al. (1960). § Glynn and Holborow (1961). ॥ Khattab and Ismail (1960).

results obtained using the Woolf method of statistical analysis comparing the incidence of the disease in non-O and $\mathrm{O}$ group persons are recorded. Note that, except for the Iowa, Liverpool, and Cairo data, the $\chi^{2}$ is not significant for the independent studies. However, the $\chi^{2}$ value for the combined data indicates a high level of significance for the blood-group association. There is no statistically significant evidence of heterogeneity between the eight groups of data.

The other investigators have not reported the $A_{1}, A_{2}$, $A_{1} B$, and $A_{2} B$ subgroups of their patients. In our data the largest relative incidence of rheumatic fever was found when group $A_{2}$ was compared with $\mathbf{O} ; \mathbf{A}_{2} \mathbf{B}$ was also more at risk than $A_{1} B$. Because of the smallness of the data and the lack of confirmation from other studies, it is not justifiable to conclude that this finding indicates a peculiar susceptibility of $\mathbf{A}_{2}$ persons to rheumatic fever. Our data suggest that $\mathbf{B}$ group persons behave similarly to A group persons with regard to the rheumatic fever association. This is supported by the findings of the other investigators.

The results of the analyses of the data when they are subdivided on the basis of sex are of interest. They suggest that the ABO "effect" may be more marked in women than in men. This sex association is most striking 
when the group $A B$ to $O$ comparison is made, but is reflected in the other comparisons as well.

The data suggest that the ABO blood-group association is strongest in the patients who were not operated upon. Several possible explanations may be considered. It could mean that the surgery and no-surgery patient groups did not have the same kind of disease-that is, the disease process that resulted in stenosis of the mitral valve, which provided the indication for surgery, differs in some way from the disease process in the other patients which did not cause mitral stenosis. It is possible that one or the other of these patient groups included patients who, in fact, did not have rheumatic fever, which would influence the observed ABO bloodgroup frequencies. The third and most plausible explanation is that the differences reflect the small volume of the data and will disappear when more data become available.

The question of age has been investigated. The ABO association did not appear to differ when the patients were subdivided by age decade. The number of patients of each decade were too few to justify a definite statement on this point. This same limitation of size of sample holds in interpreting the findings for the nonrheumatic-fever collagen-vascular diseases. It will be necessary to obtain many more data before it can be definitely stated that there are no $\mathrm{ABO}$ associations in these disorders.

Unaffected siblings used as controls eliminate the possibility that the patients and controls have inadvertently been selected from different strata of the population (Clarke et al., 1956). The family data show that the blood-group-O frequency of the patients or propositi is less than would be expected as determined from the blood-type frequencies of their unaffected siblings. The difference between the expected and observed blood-type frequency is of "borderline" significance. If the more sensitive one-tail test is used as indicated in Table VI, the difference is significant at the $5 \%$ level. Since the results of the blood-group studies lead us to expect a decreased frequency of blood group $O$ in the patients compared with their unaffected siblings, the use of the one-tail test is appropriate. These data have also been examined in another way. The group A frequency of the patients or propositi has been compared with the group A frequency of their unaffected siblings using Smith's method. An excess of type A was found in the patients compared with their unaffected siblings. Although the results of both analyses have only "borderline" significance they are important, as they are consistent with the overall findings and thus support the concept of a causal association between the ABO blood groups and rheumatic fever.

Other investigators have reported studies of the secretion of $\mathrm{ABO}(\mathrm{H})$ mucopolysaccharide blood-group substances in rheumatic-fever patients. In Table XII

TABlE XII.-Pooled Rheumatic-fever Secretor Data Analysed by Woolf's Method

\begin{tabular}{|c|c|c|c|c|c|c|c|}
\hline & & \multicolumn{2}{|c|}{ Controls } & \multicolumn{2}{|c|}{ Patients } & \multirow[b]{2}{*}{ RI } & \multirow{2}{*}{$\chi^{2}$} \\
\hline & & Secretor & $\begin{array}{c}\text { Non- } \\
\text { secretor }\end{array}$ & Secretor & $\begin{array}{c}\text { Non- } \\
\text { secretor }\end{array}$ & & \\
\hline $\begin{array}{l}\text { Iowa } \\
\text { Liverpooif } \\
\text { Taplow } \ddagger \\
\text { American§ } \\
\text { Irish§ } \quad . .\end{array}$ & $\begin{array}{l}\ldots \\
\cdots \\
\ldots\end{array}$ & $\begin{array}{r}971 \\
644 \\
516 \\
971 \\
46\end{array}$ & $\begin{array}{r}290 \\
207 \\
153 \\
290 \\
19\end{array}$ & $\begin{array}{r}279 \\
190 \\
393 \\
56 \\
36\end{array}$ & $\begin{array}{r}97 \\
73 \\
160 \\
23 \\
29\end{array}$ & $\begin{array}{l}0.86 \\
0 \cdot 84 \\
0.73 \\
0 \cdot 73 \\
0.51\end{array}$ & $\begin{array}{l}1 \cdot 26 \\
1 \cdot 26 \\
5 \cdot 82 * \\
1 \cdot 54 \\
3 \cdot 27\end{array}$ \\
\hline
\end{tabular}

Association d.f. $1 ; \chi^{2} 10 \cdot 81^{* *}$. Heterogeneity d.f $4 ; \chi^{2} 2 \cdot 34$.

* $\mathbf{p}<0.05$ ** $\mathbf{P}<0.01$ + Clarke et al. (1960). \& Glynn and Holborow (1961). their data are recorded, combined with the Iowa data, and examined for statistical significance by the method of Woolf. In evaluating the "American" data (Glynn and Holborow, 1961), the Iowa controls (II) have been used. Note that in each study the frequency of $\mathrm{ABO}(\mathrm{H})$ secretion was higher in the patients than in the controls. The difference between the patients and controls is significant only in the instance of the Taplow studies. However, the analysis of the combined data indicates a high level of statistical significance for association with no significant heterogeneity between the five groups of data.

In interpreting the results of the $\mathrm{ABO}(\mathrm{H})$ salivasecretion studies it is important to raise several questions. The techniques used to determine $\mathrm{ABO}(\mathrm{H})$ secretion in some of the investigations are open to criticism. Another important question is related to the diagnostic criteria which were used to select the patients. However, the evidence in favour of an association between $\mathrm{ABO}(\mathrm{H})$ secretion and rheumatic fever characterized by a higher incidence of the disorder in nonsecretors is strong enough to suggest that it cannot be totally discounted by these and other criticisms which may be levelled at these researches. The findings suggest that the secretion of the blood-group substances in saliva protects against rather than promotes the development of the disease, as was suggested in the introduction.

Glynn and Holborow (1961) suggested the hypothesis that rheumatic fever occurs only in individuals homozygous or heterozygous for the non-secretor gene and that individuals homozygous for secretion are immune to the disease. The secretor-gene frequencies calculated on the basis of their findings were consistent with this hypothesis. The results of family studies which these authors carried out to test the validity of the hypothesis were likewise consistent. Unfortunately, we have no family $\mathrm{ABO}(\mathrm{H})$ secretor data which can be used to test the validity of this concept.

The relative incidence of rheumatic fever in persons of $\mathrm{Rh}+$ and $\mathrm{Rh}$ - phenotypes does not significantly differ, as indicated by the non-rr to $\mathrm{rr}$ comparison in Table VIII. The rhesus "effect" becomes evident when the patients are grouped using $\mathrm{rh}^{\prime}, \mathrm{rh}^{\prime \prime}$, and $\mathrm{hr}^{\prime}$ in addition to the $\mathrm{Rh}_{\mathrm{o}}$ antisera. The rhesus "effect," characterized by an increased incidence of the disease in persons of the $R_{2} r$ and $\left(r^{\prime} r^{\prime \prime}\right) r$ presumptive genotypes, appears to be stronger than the ABO "effect." This is suggested by the larger differences between the patients and controls in the rhesus data, resulting in higher levels of statistical significance with fewer data. The differences between the patients and controls are similarly greater in the MN than in the ABO data.

The possibility has been suggested that the excess of patients compared with controls of the $\left(r^{\prime} r^{\prime \prime}\right) r$ genotype might be due to a serological peculiarity which sometimes occurs with rheumatic fever. This possibility is being investigated by performing the appropriate additional serological tests upon the blood of the patients in question.

The associations between rheumatic fever and the $\mathrm{ABO}$, rhesus, and $\mathrm{MN}$ blood-group systems raises the question of interaction between the blood-group systems. This possibility has been explored by comparing rhesus and MN blood-group frequencies of rheumatic-fever patients of $\mathrm{O}$ and non-O blood groups. No evidence of a statistically significant combined "effect" was 
found (Buckwalter and Tweed, 1962). However, the volume of the data available for analysis is much too small to categorically rule out this possibility. It is also possible that combined "effects" exist with ABO $(\mathrm{H})$ secretion, or with "effects" of the other blood-group systems which have not been investigated.

The findings presented and discussed appear to provide a definite and affirmative answer to the question: Is there an association between the blood groups and rheumatic fever? However, in interpreting the meaning of the rheumatic-fever findings and the findings of all studies concerned with the association of blood groups and disease, it is important never to forget several criticisms of these researches. The first is related to the patient-material. The diagnoses in the patients who provided the material for this report were established by different clinicians on the basis of the usual criteria used in this disease. Undoubtedly patients have been included inadvertently who did not have rheumatic fever. A second factor affecting the bloodtype frequencies in a way which cannot be measured is that some of the patients, in addition to having rheumatic fever, also had one or more other disorders, such as duodenal ulcer. In such patients there would be conflicting "blood-group effects" associated with multiple disorders. This factor cannot be eliminated by excluding patients with multiple disorders (less than $5 \%$ of the patients included in this report), since there are additional rheumatic-fever patients who are currently free of a second disorder but are nevertheless " genetically predisposed" to other disorders which ultimately will become clinically manifest. Finally, as has been suggested in this report, and by Buckwalter and Knowler (1958), the controls for blood-group disease researches leave much to be desired.

If it be granted that a causal association exists between rheumatic fever and the blood groups, we are then confronted by the even more challenging and difficult questions related to the nature of the association. At the present time virtually nothing is known concerning the mechanisms responsible for the association in rheumatic fever or the associations between other diseases and the blood groups. The evidence for the associations in rheumatic fever is not as strong as that in some other disorders, as, for example, the association of duodenal ulcer to $\mathrm{ABO}(\mathrm{H})$ secretion and to the $\mathrm{ABO}$ and rhesus blood groups (Buckwalter, 1962). However, in rheumatic fever evidence of association has been found for all blood-group systems thus far studied as well as for the association to $\mathrm{ABO}(\mathrm{H})$ secretion, which is not true for duodenal ulcer or any other disease thus far studied. On the other hand, it is most unlikely that statistically significant associations exist between rheumatic fever and all chromosome markers such as the blood groups. It is probable that as the results of similar studies conducted by other investigators accumulate, making it possible to interpret more properly the findings herein reported, some of the tentative conclusions suggested will need to be revised.

Finally, it is probable that the blood-group associations indicate the important part that genetic composition plays in the aetiology and pathogenesis of rheumatic fever. There is need for similar studies in other populations in order to evaluate more critically the findings reported in this communication. There is a challenge to design new experimental approaches, the results of which may bring understanding of the nature of the association.

\section{APPENDIX}

\author{
BY
}

\section{J. H. EDWARDS, M.B., M.R.C.P. \\ Department of Social Medicine, \\ Medical School, Birmingham 17, England}

The interpretation of observations relating blood groups to disease is difficult, and the difficulties can only partially be resolved by statistical methods. It is well known that almost all diseases, including those of the foetus, show marked differences in incidence in relation to sex, a fact not usually disputed on theoretical grounds. That other characteristics determined at conception should be related to liability to disease is of interest in relation both to the mechanisms of disease and to the nature of these inherited variations. The reliable recognition of such associations, and the dissociation of such effects from secondary associations, can never be wholly objective. The problems are similar to those of relating smoking to cancer. Standard statistical procedures are rigorously appropriate to experimental situations, and their use in observational studies is a rough and potentially dangerous approximation. Although high levels of significance may reasonably be regarded as necessary they cannot be regarded as sufficient, and the very highest levels are no defence against bias.

Consistency between different series is of great value, but it is questionable if lack of evident heterogeneity, in statistical terms, is less misleading than unaided judgment. Significance tests alone are of little value, and if estimation is made conditional on significance such estimates will be biased by exaggeration. These hazards are somewhat reduced by primarily applying estimation procedures such as that of Woolf, which is easily intelligible and simple to compute. There are numerous possible comparisons, and fortuitous associations can only be reduced by asking the most precise and mutually irrelevant questions. This excludes the use of $\chi^{2}$ for multiple degrees of freedom, for each degree of freedom relates to a different question. A simple approach is to define one phenotype as an arbitrary baseline. This phenotype should be both homozygous and common. In the $\mathrm{ABO}$ system group $\mathrm{O}$, in the secretor system ss, in the MN system MM, and in the rhesus system, in most races, $d / d$ or cde/cde, are convenient. Although minimized, the variety of significance tests is still adequate for confusion, and isolated findings unsupported by other series, or by associations with other alleles, or in similar diseases, must await confirmation.

The association of rheumatic fever with both the ABO and secretor systems would seem clearly established. In the $\mathrm{ABO}$ system group $\mathrm{A}$, group $\mathrm{B}$, and group $\mathrm{AB}$ differ considerably, consistently, and similarly from group $O$. In view of the association of both secretor and ABO status in other conditions the acceptance of either association should make us more receptive to our acceptance of the other.

It is convenient to summarize the information from both the Iowa and the other series shown in Table XIII. The notation follows Woolf. This fact of the association of liability to rheumatic fever with one blood group system reduces the threshold of incredulity in accepting associations with other systems. However, the association with the MN system is confused by the considerable divergence between the incidence of $\mathrm{MN}$ found in the controls and that found in most other series, or expected on the assumption that heterozygote advantage is slight. There is very suggestive evidence that if the effects are not primary then the chances of misclassification of $\mathrm{MN}$ differ in the presence of rheumatic fever or its sequelae. The extraordinary excess of a rare rhesus phenotype is similarly suggestive of yet another peculiar serological manifestation of rheumatic fever.

\section{Summary}

The results of investigations designed to study the possible association of rheumatic fever and the blood 
TABLE XIII.-Summary of the Pertinent Results of the Statistical Analysis of the ABO Data (Iowa and Combined)

\begin{tabular}{|c|c|c|c|c|c|}
\hline Source & $\begin{array}{c}\text { No. } \\
\text { Patients }\end{array}$ & $\begin{array}{l}\text { Infor- } \\
\text { mation } \\
(\text { w or } \\
\text { Sw) }\end{array}$ & $\begin{array}{c}\text { Estimated (y) } \\
\text { or Mean } \\
\text { Weighted } \\
\text { Estimator } \\
\text { (Swy/Sw) } \\
\text { with Standard } \\
\text { Error }\end{array}$ & $\begin{array}{c}\text { Relative } \\
\text { Incidence } \\
\text { (Expon- } \\
\text { ential } \\
\text { of } \\
\text { y or } \\
\text { Swy Sw) }\end{array}$ & $\begin{array}{c}\text { Main } \\
\text { Effect } \\
\\
\text { square } \\
\text { wy or or } \\
\left(\mathbf{S w y}^{2}\right. \\
(\mathbf{S w})\end{array}$ \\
\hline $\begin{array}{c}\text { Secretor against } \\
\text { non-secretor: } \\
\text { lowa } \\
\text { Table XiI } \quad \cdots\end{array}$ & $\begin{array}{r}376 \\
1,192\end{array}$ & $\begin{array}{r}54 \cdot 43 \\
151 \cdot 80\end{array}$ & $\begin{array}{l}0.1519 \pm 0.1355 \\
0.2218 \pm 0.0812\end{array}$ & $\begin{array}{l}1 \cdot 16 \\
1 \cdot 25\end{array}$ & $\begin{array}{l}1 \cdot 26 \\
7 \cdot 47 * *\end{array}$ \\
\hline $\begin{array}{c}\text { Group } \mathbf{A} \text { against } \\
\text { Group O: } \\
\begin{array}{c}\text { Iowa } \\
\text { Table XI }\end{array}\end{array}$ & $\begin{array}{r}661 \\
2,475\end{array}$ & $\begin{array}{l}162.03 \\
577.00\end{array}$ & $\begin{array}{l}0 \cdot 1937 \pm 0.0786 \\
0 \cdot 1358 \pm 0.0416\end{array}$ & $\begin{array}{l}1.21 \\
1 \cdot 15\end{array}$ & $\begin{array}{l}6 \cdot 08^{* *} \\
10 \cdot 65^{* * *}\end{array}$ \\
\hline $\begin{array}{c}\text { Group } \mathbf{\text { B }} \text { against } \\
\text { Group O: } \\
\text { Towa } \\
\text { Table Xi }\end{array}$ & $\begin{array}{r}383 \\
1,625\end{array}$ & $\begin{array}{r}59 \cdot 34 \\
256 \cdot 38\end{array}$ & $\begin{array}{l}0.1496 \pm 0.1297 \\
0.1655 \pm 0.0627\end{array}$ & $\begin{array}{l}1 \cdot 16 \\
1 \cdot 18\end{array}$ & $\begin{array}{l}1.33 \\
6.97 * *\end{array}$ \\
\hline $\begin{array}{c}\text { Group } A B \text { against } \\
\text { Group O: } \\
\text { Iowa } \\
\text { Tab!e XI }\end{array}$ & $\begin{array}{r}343 \\
1,409\end{array}$ & $\begin{array}{r}30 \cdot 83 \\
114 \cdot 12\end{array}$ & $\begin{array}{l}0.3755 \pm 0.1801 \\
0.2670 \pm 0.0936\end{array}$ & $\begin{array}{l}1.46 \\
1.31\end{array}$ & $\begin{array}{l}4 \cdot 35 * \\
8 \cdot 13^{* *}\end{array}$ \\
\hline
\end{tabular}

groups are reported. Statistically significant evidence has been found in 771 rheumatic-fever patients that the liability to this disease is increased in persons who are of non-O ABO blood group, are of rhesus genotype $\mathrm{R}_{2} \mathrm{r}$ and $\left(\mathrm{r}^{\prime} \mathrm{r}^{\prime \prime}\right) \mathrm{r}, \mathrm{MN}$ group $\mathrm{N}$, and are non-secretors of $\mathrm{ABO}(\mathrm{H})$ blood-group substances. The data have been combined and statistically analysed with those reported by other investigators.

\section{REFERENCES}

Buckwalter, J. A. (1962). Ann. N.Y. Acad. Sci. To be published. — and Knowler, L. A. (1958). Amer. J. hum. Genet., 10, 164 - Tidrick, R. T., Knowler, L. A., Wohlwend, E. B., Colter, D. C., Turner, J. H., Raterman, L., Gamber, H. H., Roller, G. J., Pollock, C. B., and Naifeh, V. K. (1958). J. lowa St. med. Soc., 48. 76

- and Tweed, G. V. (1962). J. Amer. med. Ass., 179, 479.

- Van Scoy, R. E., and Knowler, L. E. (1960). Brit. med. J., 2. 1643 .

Clarke, C. A., Edwards, J. W., Haddock, D. R. W., HowelEvans, A. W., McConnell, R. B., and Sheppard, P. M. (1956). Brit. med. J., 2, 725.

- McConnell, R. B., and Sheppard, P. M. (1960). Ibid., 1, 21.

Glynn, L. E., and Holborow, E. J. (1952). J. Path. Bact., 64, 775

(1961). Arthr, and Rheum. 4, 203

Khattab, T. M., and Ismail, A. A. (1960). J. Egypt. med. Ass., 43, 441 .

Woolf, B. (1955). Ann. hum. Genet., 19, 251

The Patients' General Committee in Moorhaven Hospital, Ivybridge, Devon, has now been in force for about three years. There are 16 members-one representative from each ward. The officers of the committee are patients and no staff are present at the meetings unless invited. The committee meets each week and can discuss any subject concerned with the hospital. Members are free to criticize, and the chairman or secretary of the committee can approach members of the hospital administrative staff on committee matters. It is the custom always to invite a guest to its meetings. The guest is usually a member of the hospital staff but has included members of the Hospital League of Friends, the chairman of the hospital management committee, and, the Lord Mayor of Plymouth. One of the most recent matters discussed by the committee was how to help in an economy drive which the hospital is at present having to undertake. The committee has been very helpful in many ways, such as putting forward proposals to improve the public bus service to the hospital.

\section{A NOTABLE SOURCE OF ERROR IN THE DIAGNOSIS OF APPENDICITIS}

BY

H. E. HARDING, D.M.

Director, Salisbury Area Pathological Service

Probably no surgeon wishes to remove a normal appendix, but the number of such appendicectomies amounts to perhaps a quarter or more of the total removed. Barnes, Behringer, Wheelock, and Wilkins (1962) found that $25.3 \%$ of 7,810 appendices removed at the Massachusetts General Hospital between 1937 and 1955 were normal. From an analysis of figures supplied by the General Register Office giving the number of patients discharged from hospitals with a diagnosis of appendicitis in 1956 and 1957, Lee (1961) showed that twice as many young women aged 17 years were thus diagnosed than might be expected. He noted that although these cases had been discharged with a diagnosis of "appendicitis" there was no information about the histological findings, and he believed that the extra cases in young women were probably not due to inflammation of the vermiform appendix as commonly understood.

Appendicectomy in these circumstances may be not much more than a minor operation, but it is not entirely without risk to the patient (Barnes et al. record four deaths), and is wasteful of hospital beds and of the time of surgical teams and nurses as well as of that of the patient. Anything that would help to reduce the number of these unnecessary operations would be welcomed by patients, surgeons, and administrators. It is for this reason that this note is intended to draw attention to a group of patients in whom a mistaken diagnosis of appendicitis is made much more frequently than in the general population. It is not my belief that this is unknown to surgeons, but they may well be unaware of the magnitude of the problem.

\section{Results of Investigation}

Because of an impression that all the normal appendices I saw came from young women, I started in 1955 to pay particular attention to every appendix received from the operating-theatres, and made an effort to obtain all of them for a period of seven years. Not quite all of those removed were in fact received, but there is no reason to believe that there was any selection by age or by sex. Every appendix was examined carefully macroscopically, and at least two blocks, one from near the tip and one from the middle, were taken for microscopical examination. Only those appendices that showed no abnormality of any kind both macroscopically and histologically were labelled as normal. Of 1,300 appendices, $515(39.6 \%)$ fell into this category.

Results in Age-groups

\begin{tabular}{c|c|c|c|c|c|c}
\hline \multirow{2}{*}{ Age } & \multicolumn{3}{|c|}{ Males } & \multicolumn{3}{c}{ Females } \\
\cline { 2 - 7 } & Normal & Abnormal & \% Normal & Normal & Abnormal & $\%$ Normal \\
\hline $1-10$ & 41 & 68 & $37 \cdot 6$ & 39 & 57 & $40 \cdot 6$ \\
$11-20$ & 41 & 126 & $24 \cdot 6$ & 148 & 91 & 62.0 \\
$21-30$ & 29 & 50 & $36 \cdot 5$ & 70 & 60 & $53 \cdot 8$ \\
$31-40$ & 23 & 54 & $29 \cdot 9$ & 43 & 49 & $46 \cdot 7$ \\
$41-50$ & 12 & 37 & $21 \cdot 5$ & 26 & 55 & $32 \cdot 1$ \\
$51-60$ & 14 & 39 & $26 \cdot 4$ & 13 & 28 & $31 \cdot 7$ \\
$60+$ & 10 & 33 & $23 \cdot 3$ & 6 & 38 & $13 \cdot 6$ \\
\hline All ages & 170 & 497 & $29 \cdot 0$ & 345 & 378 & $47 \cdot 7$ \\
\hline
\end{tabular}

